\title{
Single Nucleotide Polymorphisms in the Ovine Casein Genes Detected by Polymerase Chain Reaction-Single Strand Conformation Polymorphism
}

\author{
G. Ceriotti, ${ }^{1}$ S. Chessa, ${ }^{1}$ P. Bolla, ${ }^{1}$ E. Budelli, ${ }^{2}$ L. Bianchi, ${ }^{3}$ E. Duranti, ${ }^{3}$ and A. Caroli ${ }^{4}$ \\ ${ }^{1}$ Dipartimento di Scienze e Tecnologie Veterinarie per la Sicurezza Alimentare, \\ Università degli Studi di Milano, 20134 Milano, Italy \\ ${ }^{2}$ Fondazione Parco Tecnologico Padano, Centro Ricerche e Studi Agroalimentari, \\ 20090 Segrate (Milano), Italy \\ ${ }^{3}$ Dipartimento di Scienze Zootecniche, Università degli Studi di Perugia, \\ 06100 Perugia, Italy \\ ${ }^{4}$ Dipartimento di Sanità e Benessere Animale, Università di Bari, \\ 70010 Valenzano (Bari), Italy
}

\begin{abstract}
Casein genetic polymorphisms are important and well known due to their effects on quantitative traits and technological properties of milk. At the DNA level, polymerase chain reaction (PCR)-single-strand conformation polymorphism (SSCP) allows for the simultaneous typing of several alleles at casein loci, as well as the detection of unknown polymorphisms. Here we describe the usefulness of the PCR-SSCP technique for casein typing in sheep. In particular, three single-nucleotide polymorphisms (SNP) are described at CSN1S1, CSN2, and $C S N 3$, all resulting in amino acid exchanges. At CSN1S1, a transition $\mathrm{T} \rightarrow \mathrm{C}$ was found, resulting in the deduced amino acid exchange $\mathrm{Ile}_{186} \rightarrow \mathrm{Thr}_{186}$. A transition $\mathrm{A} \rightarrow \mathrm{G}$ resulting in the deduced amino acid exchange $\mathrm{Met}_{183} \rightarrow \mathrm{Val}_{183}$ was identified at CSN2. The 2 SNP showed a rather high frequency (ranging from 0.12 to 0.26 ) in 3 Italian breeds (Sarda, Comisana, Sopravissana). Another transition $\mathrm{C} \rightarrow \mathrm{T}\left(\mathrm{Ser}_{104} \rightarrow \mathrm{Leu}_{104}\right)$ was found at CSN3 in one heterozygous animal.
\end{abstract}

(Key words: sheep, casein, genetic polymorphism, SSCP)

Abbreviation key: AS = allele specific, $\mathbf{C S N 1 S 1}=\alpha_{\mathrm{S} 1^{-}}$ casein locus, $\boldsymbol{C S N 2}=\beta$-casein locus, $\boldsymbol{C S N 3}=\kappa$-casein locus, RFLP = restriction fragment length polymorphism, $\mathbf{S N P}=$ single nucleotide polymorphism, $\mathbf{S S C P}=$ single-strand conformation polymorphism, $\mathbf{T B E}=$ Trisborate-EDTA.

\section{INTRODUCTION}

In ruminants, milk protein genetic variability is well known. This variability has been shown to affect milk

Received January 20, 2004.

Accepted April 6, 2004.

Corresponding author: G. Ceriotti; e-mail: gabriella.ceriotti@ unimi.it. composition and technological quality. Several studies have been carried out on cattle and goats (reviewed by Martin, 1993; Grosclaude et al., 1994; Di Stasio and Mariani, 2000; Rando et al., 2000), whereas ovine milk protein polymorphism has been less extensively investigated. However, an interesting and rather complex protein pattern was also found for ovine milk, but the genetic control of the variation observed was assessed only in few cases. Genetic polymorphism at the protein level was demonstrated for $\beta$-lactoglobulin (three variants: A, B and C; Bell and McKenzie, 1967; Erhardt, 1989) and $\alpha_{\mathrm{s} 1}$-casein (three variants: $\mathrm{A}, \mathrm{C}, \mathrm{Welsh} / \mathrm{D}$; King 1966; Richardson and Creamer, 1976; Ferranti et al., 1995; Chianese et al., 1996). Some evidence indicates that ovine genetic polymorphisms affect the physicochemical properties of milk (Rampilli et al., 1992; Pirisi et al., 1999). Further protein polymorphisms were detected by electrophoretic methods at $\alpha$-lactalbumin (Russo et al., 1979; Dall'Olio et al., 1989), $\alpha_{\mathrm{s} 1}$-casein (Chianese et al., 1996), $\beta$-casein (Chiofalo and Micari, 1987), and $\alpha_{\mathrm{s} 2}$-casein (Chessa et al., 2003a), but biochemical characterization, as well as genetic segregation studies, are unavailable. Two protein fractions were isolated for $\kappa$-casein almost $40 \mathrm{yr}$ ago (Alais and Jollès, 1966), but a genetic polymorphism was never suggested at the protein level. More recently, some nonallelic protein variants were found at $\alpha_{\mathrm{s} 1}$-casein and at $\alpha_{\mathrm{s} 2}$-casein (Boisnard et al., 1991; Ferranti et al., 2001). This fact makes the investigation of the ovine casein genetic variation at the protein level more complex. Moreover, the few genetic protein polymorphisms demonstrated indicate the necessity to study the ovine milk protein variation at the DNA level as well.

New DNA technologies provide the opportunity to clearly identify the genetic polymorphisms, to detect further genetic variation, and to develop analytical tests particularly suitable for milk protein genotyping. In the ovine species, allele specific (AS)-PCR was used 
Table 1. For each locus, the accession number (Acc. no.) of the reference and the new GenBank sequence, the single-nucleotide polymorphism (SNP) detected, the deduced AA exchanged in the mature protein sequence, and frequencies in the different breeds are presented. The nucleotide position of the SNP is referred to the respective GenBank sequence.

\begin{tabular}{lllllll}
\hline Locus & Acc. no. & $\mathrm{SNP}$ & $\mathrm{AA}$ & $\begin{array}{l}\text { Comisana } \\
(\mathrm{n}=59)\end{array}$ & $\begin{array}{l}\text { SNP frequency } \\
\text { Sarda } \\
(\mathrm{n}=45)\end{array}$ & $\begin{array}{l}\text { Sopravissana } \\
(\mathrm{n}=34)\end{array}$ \\
\hline CSN1S1 & $\mathrm{X}$ 03237 & $\mathrm{T}_{663}$ & $\mathrm{Ile}_{186}$ & 0.737 & 0.878 & 0.809 \\
& $\mathrm{AY444506}$ & $\mathrm{C}_{137}$ & $\mathrm{Thr}_{186}$ & 0.263 & 0.122 & 0.191 \\
CSN2 & $\mathrm{X} 79703$ & $\mathrm{~A}_{12029}$ & $\mathrm{Met}_{183}$ & 0.763 & 0.756 & 0.824 \\
& $\mathrm{AY444504}$ & $\mathrm{G}_{226}$ & $\mathrm{Val}_{183}$ & 0.237 & 0.244 & 0.176 \\
CSN3 & $\mathrm{X} 51822$ & $\mathrm{C}_{443}$ & $\mathrm{Ser}_{104}$ & 1.000 & 1.000 & 0.985 \\
& $\mathrm{AY444505}$ & $\mathrm{T}_{164}$ & $\mathrm{Leu}_{104}$ & 0.000 & 0.000 & 0.015 \\
\hline
\end{tabular}

to identify $\alpha_{\mathrm{s} 1}$-casein $\mathrm{D}$ (Ramunno et al., 1997) at the DNA level. Successively, PCR-restriction fragment length polymorphism (RFLP) tests were already developed for the identification of $\alpha_{\mathrm{s} 1}$-casein A, C, D (Pilla et al., 1998) and $\beta$-lactoglobulin A, B variants (Feligini et al., 1998).

Among the DNA technologies, polymerase chain reaction-single-strand conformation polymorphism (SSCP) is a powerful tool for milk protein analysis, allowing for the simultaneous typing of different alleles at $\alpha_{\mathrm{s} 1^{-}}$ (CSN1S1), $\beta$ - (CSN2), and $\kappa^{-}$(CSN3) casein loci. This method was successfully used for the analysis of bovine CSN2 (Barroso et al., 1999) and CSN3 (Prinzenberg et al., 1999). The same technique was used to differentiate $C S N 1 S 1^{*} B$ from $C S N 1 S 1^{*} C$ in cattle (Jann et al.,

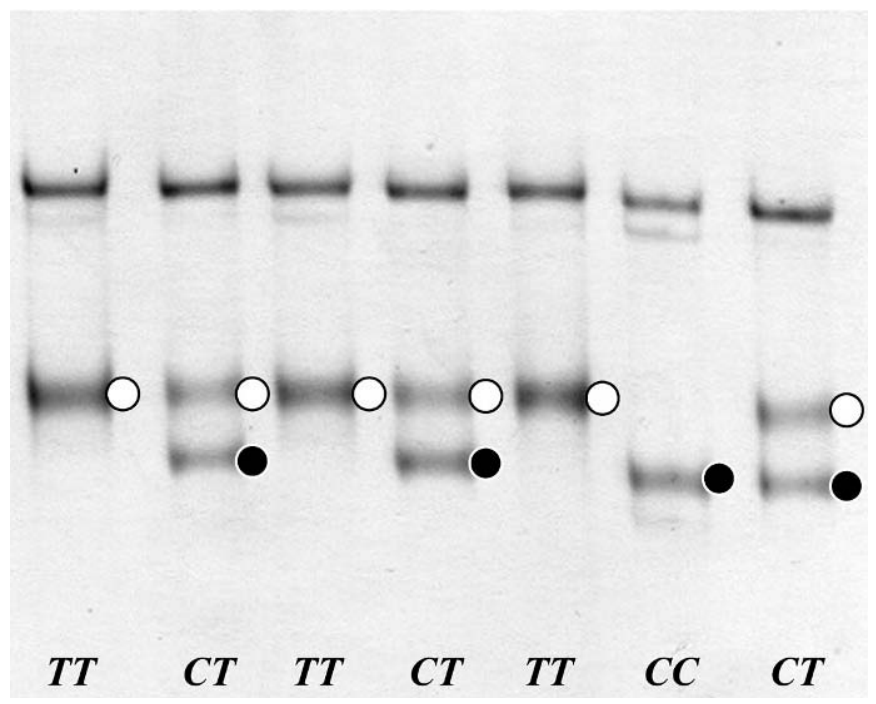

Figure 1. The PCR-single-strand conformation polymorphism (SSCP)-based DNA test for $\alpha_{\mathrm{s} 1}$-casein locus (CSN1S1) exon 17 polymorphism. The black and the white dots indicate $\mathrm{C}$ and $\mathrm{T}$ occurrence, respectively, in the nucleotide sequence. The second band of each single-nucleotide polymorphism migrates at the same level of the first one and therefore is not visible in this figure. 2002b) and to identify a new bovine CSN2 allele (CSN2*I; Jann et al., 2002a).

In goats, PCR-SSCP method was found to be particularly useful for CSN3 analysis (Chessa et al., 2003b), allowing discrimination of variants in addition to the $A$ and $B$ alleles previously described (Caroli et al., 2001). The PCR-SSCP technique is therefore an alternative to other methods such as PCR-RFLP (Yahyaoui et al., 2001) and primer extension analysis (Yahyaoui et al., 2003) for caprine CSN3 typing.

In sheep, Bastos et al. (2001) used PCR-SSCP to analyze CSN1S1, CSN2, and CSN3. Polymorphic patterns were found at the first 2 loci, but no further information was provided regarding the biochemical characterization of the patterns observed.

In an effort to learn more about ovine casein genetic variation, we developed PCR-SSCP analysis for this species, looking at further polymorphisms at CSN1S1, CSN2, and CSN3 loci. Deeper knowledge of the casein genetic variation in the ovine species is needed for use in biodiversity studies and in investigations of relationships between genetic polymorphisms and traits of economical interest (i.e., milk quantitative and qualitative production, and technological and nutritional properties of milk).

\section{MATERIALS AND METHODS}

\section{Samples}

Blood samples of 138 animals belonging to 3 Italian sheep breeds (Comisana $\mathrm{n}=59$, Sarda $\mathrm{n}=45$, and Sopravissana $\mathrm{n}=34$ ) were randomly collected avoiding narrow genetic relationships among the sampled animals, and DNA was extracted from blood by a commercial kit (GFXTM Genomic Blood DNA Purification Kit, Amersham Biosciences, Piscataway, NJ). Two of these breeds, Sarda and Comisana, are the most consistent dairy sheep breeds in Italy, whereas the third, Sopravissana, is an Italian Merino breed, used for milk, meat, 


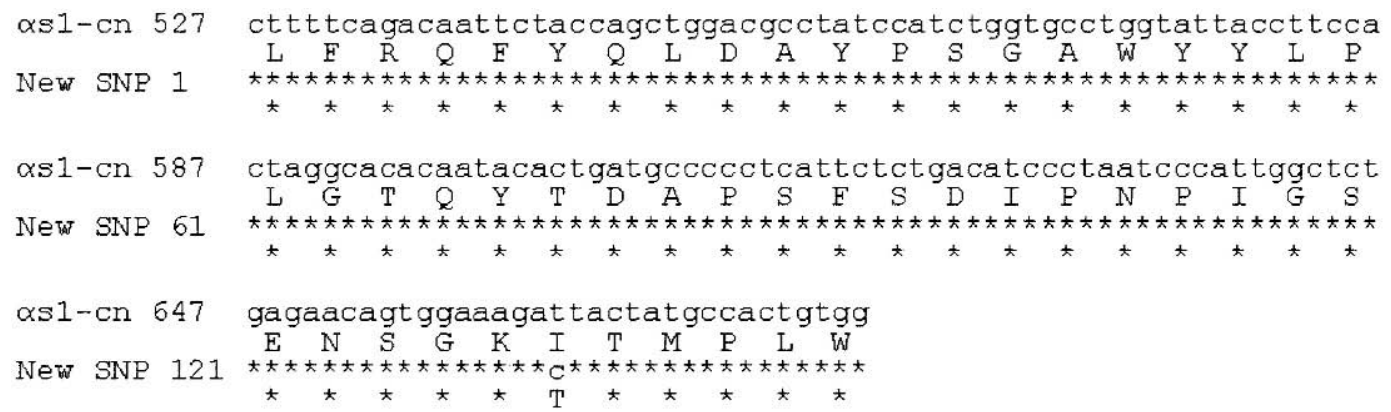

Figure 2. Sequence comparison of positions 527 to 679 of the published mRNA $\alpha_{\mathrm{s} 1}$-casein locus (CSN1S1) sequence (GenBank accession no. X03237) and the codified protein sequence (first and second sequence, respectively) vs. the DNA and deduced AA sequences (GenBank accession no. AY444506) found in the present work (new single-nucleotide polymorphism: third and fourth sequence respectively). Identical nucleotides and AA are replaced by * and the substitutions are written as letter.

and wool (http://www.tiho-hannover.de/einricht/zucht/ eaap/).

\section{PCR-SSCP Analysis}

Different PCR-SSCP methods available for cattle or goat casein typing were adapted to analyze the DNA ovine samples by using a PTC-200 Peltier Thermal Cycler (MJ Research Inc., Waltham, MA), a vertical electrophoresis apparatus (Penguin Dual Gel Water-Cooled Electrophoresis System, OWL Scientific Inc., Woburn, MA), and silver staining (Bassam et al., 1991) to visualize the bands.

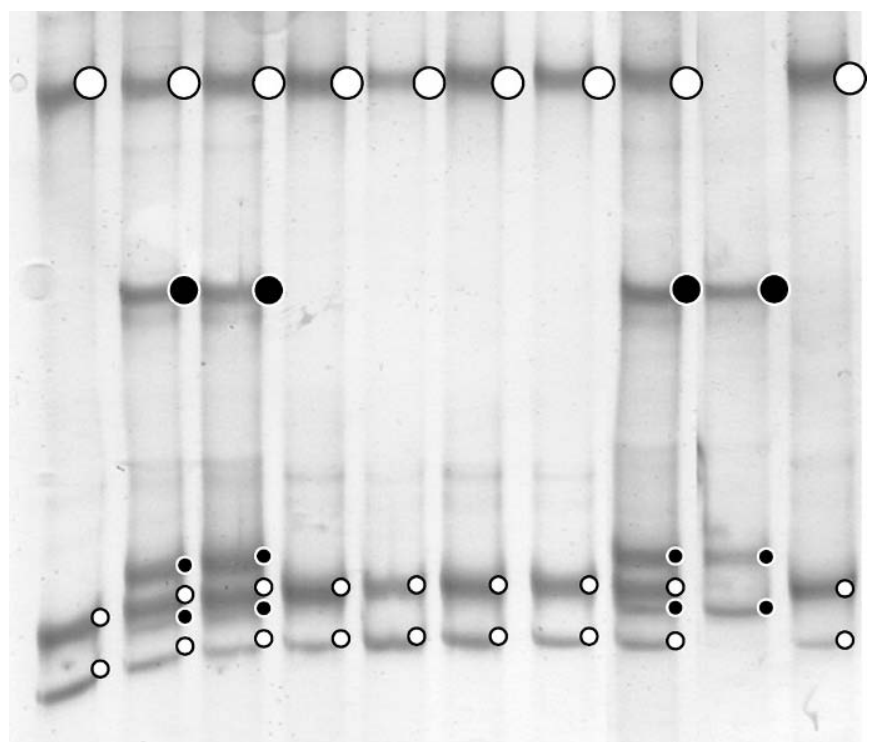

\section{AA AG AG AA AA AA AA AG GG AA}

Figure 3. The PCR-single-strand conformation polymorphism (SSCP)-based DNA test for $\beta$-casein locus (CSN2) exon 7 polymorphism. The black and the white dots indicate G and A occurrence, respectively, in the nucleotide sequence.
The following PCR-SSCP analyses were performed: CSN1S1: A presumably 223-bp-long fragment containing exon 17 of the sheep CSN1S1 gene was amplified by a PCR performed in a $25-\mu \mathrm{L}$ reaction mixture containing $2 \mu \mathrm{L}$ of DNA solution (100 to $150 \mathrm{ng}$ ), $10 \mathrm{pmol}$ of each primer, and $1 \times$ PCR Master Mix (Fermentas, Vilnius, Lithuania). Primers, PCR, and SSCP conditions were as described by Jann et al. (2002b) to differentiate the bovine $C S N 1 S 1^{*} B$ and $C$ alleles. Primers: 5' CAC TGT TGC TTT TTC AAT GGT C 3'; 5' AAG GCA ACA ATA TGC AGT CAT TT $3^{\prime}$. The PCR conditions were as follows: $94^{\circ} \mathrm{C}$ for $5 \mathrm{~min}$; $30 \times\left(94^{\circ} \mathrm{C}\right.$ for 1 $\min , 56^{\circ} \mathrm{C}$ for $1 \mathrm{~min}, 72^{\circ} \mathrm{C}$ for $1 \mathrm{~min}$ ); $72^{\circ} \mathrm{C}$ for $5 \mathrm{~min}$.

The SSCP analysis was carried out as follows: $4 \mu \mathrm{L}$ of PCR product was added to $6 \mu \mathrm{L}$ of denaturating solution (0.025\% of xylene-cyanol, $0.025 \%$ of bromophenol blue, and 0.02 $M$ EDTA in deionized formamide). After heat denaturation $\left(91^{\circ} \mathrm{C}\right.$ for $\left.3 \mathrm{~min}\right)$, the samples were immediately chilled on ice and then run $\left(3 \mathrm{~h}, 200 \mathrm{~V}, 10^{\circ} \mathrm{C}\right)$ on $10 \%$ acrylamide:bisacrylamide gels (37:1) with $2 \%$ glycerol in 0.5× Tris-borate-EDTA (TBE) buffer.

For CSN2, a 299-bp fragment containing exon 7 of the sheep CSN2 gene was amplified by a PCR performed in a $25-\mu \mathrm{L}$ reaction mixture containing $2 \mu \mathrm{L}$ of DNA solution (100 to $150 \mathrm{ng}$ ), $10 \mathrm{pmol}$ of each primer, and $1 \times$ PCR Master Mix (Fermentas). The primers used were the ones described by Ramunno et al. (1995) to amplify the caprine A allele. Primers: 5' CGT GCT GTC CCT TTC TC 3'; 5' GTT TTC CAG CTT ATT CTA TTT AT $3^{\prime}$. Polymerase chain reaction conditions: $95^{\circ} \mathrm{C}$ for $2 \mathrm{~min} ; 30 \times\left(94^{\circ} \mathrm{C}\right.$ for $45 \mathrm{~s}, 52^{\circ} \mathrm{C}$ for $45 \mathrm{~s}, 72^{\circ} \mathrm{C}$ for 3 $\min ) ; 72^{\circ} \mathrm{C}$ for $5 \mathrm{~min}$.

The SSCP analysis was carried out as follows: $6 \mu \mathrm{L}$ of PCR product and $8 \mu \mathrm{L}$ of denaturating solution ( $0.05 \%$ of xylene-cyanol, $0.05 \%$ of bromophenol blue, and 0.02 $M$ EDTA in deionized formamide); heat denaturation $\left(95^{\circ} \mathrm{C}\right.$ for $\left.7 \mathrm{~min}\right)$; and a 15 -h run $\left(280 \mathrm{~V}, 5^{\circ} \mathrm{C}\right)$ 


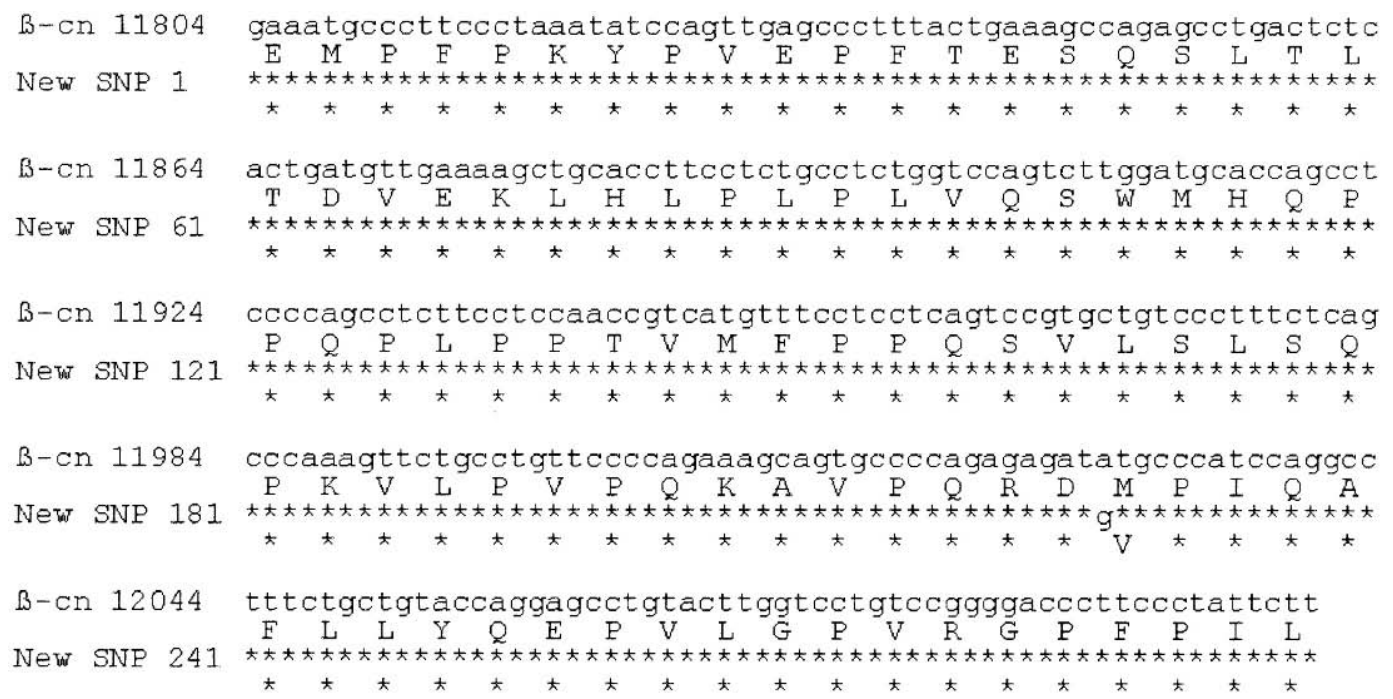

Figure 4. The sequence comparison of nucleotide positions 11804 to 12100 of the published $\beta$-casein locus (CSN2) sequence (GenBank accession no. X79703) and the codified protein sequence (first and second sequence respectively) vs. the DNA and deduced AA sequences (GenBank accession no. AY444504) found in the present work (new single-nucleotide polymorphism: third and fourth sequence respectively). Identical nucleotides and AA are replaced by $*$ and the substitutions are written as a letter.

on $10 \%$ acrylamide:bisacrylamide gels $(29: 1)$ with $0.5 \%$ glycerol in $0.5 \times$ TBE buffer.

For CSN3, a 406-bp fragment containing exon 4 of the ovine CSN3 was amplified by PCR and then analyzed by SSCP as described by Chessa et al. (2003b) for goat CSN3 polymorphism detection. Primers were $5^{\prime}$ GGT ATC CTA GTT ATG GAC TCA AT $3^{\prime}$; $5^{\prime}$ GTT GAA GTA ACT TGG GCT GTG T $3{ }^{\prime}$. The PCR conditions were: $95^{\circ} \mathrm{C}$ for $2 \mathrm{~min} ; 35 \times\left(94^{\circ} \mathrm{C}\right.$ for $1 \mathrm{~min}, 59^{\circ} \mathrm{C}$ for $40 \mathrm{~s}$, $72^{\circ} \mathrm{C}$ for $3 \mathrm{~min}$ ); $72^{\circ} \mathrm{C}$ for $5 \mathrm{~min}$. The SSCP analysis was carried out as follows: $6 \mu \mathrm{L}$ of PCR product, $8 \mu \mathrm{L}$ of denaturing solution $(0.05 \%$ of xylene-cyanole, $0.05 \%$ of bromophenol blue and 0.02 $M$ EDTA in deionized formamide); heat denaturation $\left(95^{\circ} \mathrm{C}\right.$ for $\left.7 \mathrm{~min}\right)$; and a 17-h run overnight $\left(340 \mathrm{~V}, 5^{\circ} \mathrm{C}\right)$ on $9.25 \%$ acrylamide:bisacrylamide gels (29:1) with $1 \%$ glycerol in $0.5 \times \mathrm{TBE}$ buffer.

\section{DNA Sequencing}

The DNA samples showing different patterns on SSCP gels were selected for sequencing. Three sup-

Table 2. Casein haplotype frequencies in the different breeds under the hypothesis of independent segregation (I) and taking into account association among loci (A).

\begin{tabular}{|c|c|c|c|c|c|c|c|}
\hline \multicolumn{2}{|c|}{ Haplotype } & \multicolumn{2}{|c|}{ Comisana } & \multicolumn{2}{|c|}{ Sarda } & \multicolumn{2}{|c|}{ Sopravissana } \\
\hline CSN1S1 & CSN2 & I & $\mathrm{A}$ & I & $\mathrm{A}$ & I & $\mathrm{A}$ \\
\hline$T$ & $A$ & 0.562 & 0.514 & 0.663 & 0.647 & 0.666 & 0.723 \\
\hline$T$ & $G$ & 0.175 & 0.223 & 0.215 & 0.230 & 0.143 & 0.085 \\
\hline$C$ & A & 0.200 & 0.248 & 0.092 & 0.108 & 0.157 & 0.100 \\
\hline$C$ & $G$ & 0.062 & 0.014 & 0.030 & 0.014 & 0.034 & 0.091 \\
\hline
\end{tabular}

posed heterozygous samples, and 3 further samples that were supposedly homozygous for the more common SSCP pattern, were randomly chosen both for CSN1S1 and for CSN2. The unique sample supposed to be heterozygous for CSN3 was amplified and subsequently sequenced 3 times, and 3 samples randomly chosen among all the others showing the more common SSCP pattern were also sequenced for CSN3. Primers used for sequencing were the same as those used for the PCR-SSCP techniques, with the exception of the CSN2, for which the following primers were used: $5^{\prime}$ CCC AAA GTG AAG GAG ACT ATG 3', 5' CAT CAG AAG TTA AAC AGC ACA G 3'. The PCR products were sequenced by PRIMM Srl (Milan, Italy). The nucleotide sequences and the deduced AA sequences were analyzed with Bioedit (Hall, 1999) software.

\section{Data Analysis}

Allele frequencies, observed and expected genotype frequencies, and eventual deviations from Hardy-Weinberg equilibrium were evaluated by GENEPOP software (Raymond and Rousset, 1995). Moreover, the genotypic combinations were analyzed to assess the variability of the casein haplotypes due to the tight linkages between the casein loci (Ferretti et al., 1990; Threadgill and Womack, 1990). In particular, CSN1S1 and CSN2 were analyzed due to the very low frequency of the SNP detected for CSN3. Casein haplotype frequencies and the occurrence of linkage disequilibrium were estimated with EH software (Xie and Ott, 1993). 


\section{RESULTS AND DISCUSSION}

An SNP was identified in each locus and characterized by sequencing. Polymorphisms were named with the different nucleotide occurring in the DNA sequence (Table 1).

\section{Casein Locus CSN1S1}

The PCR-SSCP analysis of exon 17 revealed 2 distinct patterns (Figure 1). The more common pattern corresponded to the sequencing results of the GenBank accession no. X03237 published sequence. The sequencing of the new pattern (GenBank accession no. AY444506) revealed a transition $\mathrm{T} \rightarrow \mathrm{C}$ at position 663 of the referring sequence, resulting in the deduced AA exchange $\mathrm{Ile}_{186} \rightarrow \mathrm{Thr}_{186}$ (Figure 2).

Such a polymorphism had not been described before. In fact, the already characterized ovine CSN1S1 variants, $A, C$, and $D$, involve different AA substitutions (Ferranti et al., 1995). The $C$ variant differs from $A$ by having a Pro instead of Ser at position 13, whereas the $D$ variant is characterized by a further substitution at position $68\left(\mathrm{Ser}_{68} \rightarrow \mathrm{Asn}_{68}\right)$. The exons involved in these substitutions are exon 3 and exon 9, respectively (Ramunno et al., 1997; Pilla et al., 1998). From a theoretical point of view, the exchange detected here could not be recognized at the protein level using electrophoretic methods, because Ile and Thr are both neutral.

At the DNA level, a polymorphic SSCP pattern was recently detected but not characterized in ovine CSN1S1 exons 10 and 11 (Bastos et al., 2001). Therefore, this pattern is not related to the new SNP detected, which involves exon 17.

The frequency of the $C$ SNP was $26.3 \%$ in the Comisana, $12.2 \%$ in the Sarda, and $19.1 \%$ in the Sopravissana breeds (Table 1). Hardy-Weinberg equilibrium was verified in all breeds.

\section{Casein Locus CSN2}

Two distinct patterns were found by PCR-SSCP analysis of exon 7 (Figure 3). The pattern corresponding to the sequence results in the published sequence (GenBank accession no. X79703) was indicated as $A$, whereas the new pattern was denominated as $G$. In fact, the sequence analysis of the 2 patterns (GenBank Accession Number AY444504) revealed the presence of a transition $\mathrm{A} \rightarrow \mathrm{G}$ at position 12029 of the referring sequence, resulting in the deduced AA exchange Met $_{183}$ $\rightarrow \mathrm{Val}_{183}$ (Figure 4). This exchange could not be recognized at the protein level using electrophoretic methods, because Met and Val are both neutral.

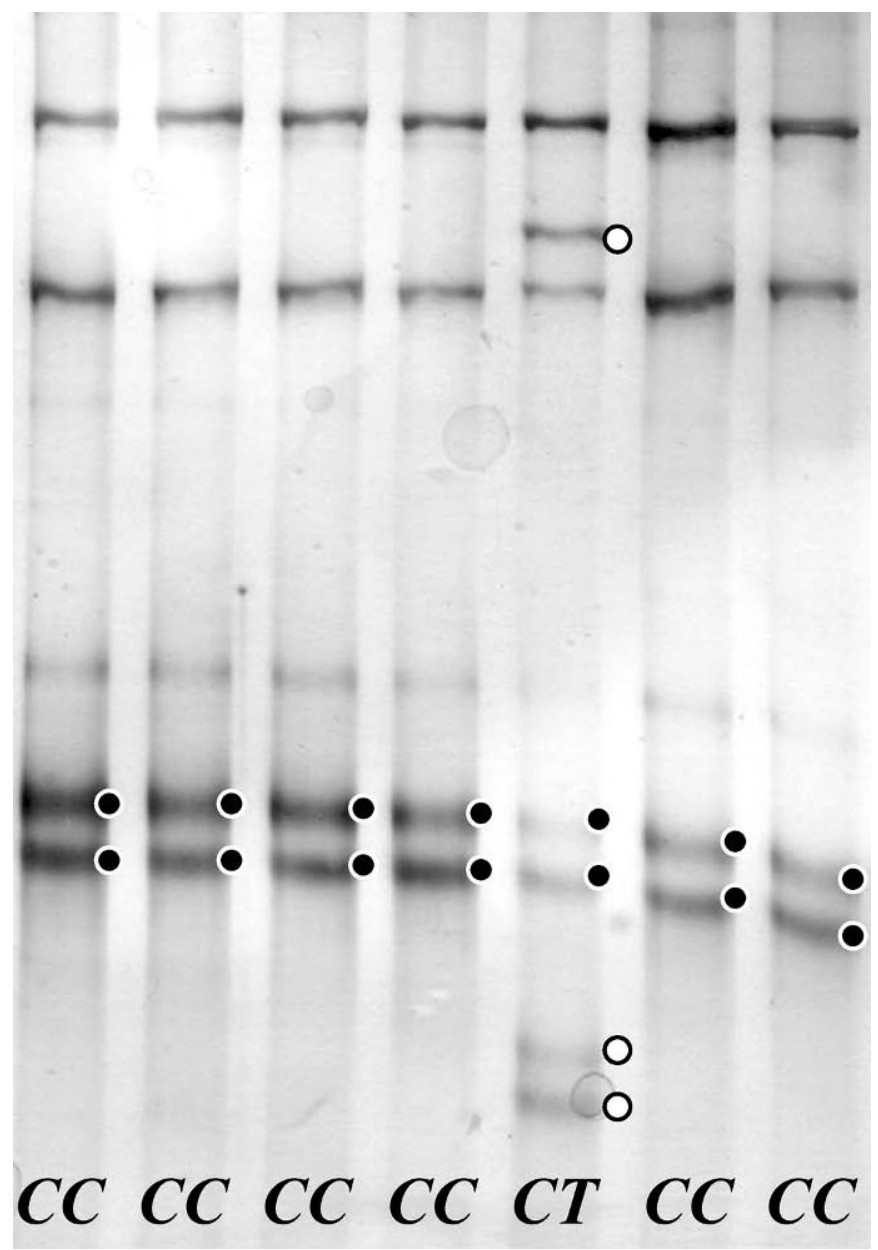

Figure 5. The PCR-single-strand conformation polymorphism (SSCP)-based DNA test for $\kappa$-casein locus (CSN3) exon 4 polymorphism. The black and the white dots indicate $\mathrm{C}$ and $\mathrm{T}$ occurrence, respectively, in the nucleotide sequence.

A polymorphic pattern was already described in exon 7 by SSCP (Bastos et al., 2001), but no information was provided for its biochemical characterization. The nucleotide fragment analyzed was longer than in the present work and was comprehensive of the nucleotide sequence typed here, so the 2 polymorphisms could match.

The frequency of $G$ SNP was $23.7 \%$ in the Comisana, $24.4 \%$ in the Sarda, and $17.6 \%$ in the Sopravissana breed (Table 1). Hardy-Weinberg equilibrium was verified also for CSN2 in all breeds.

\section{Casein Locus CSN3}

The PCR-SSCP analysis of exon 4 showed 2 different patterns (Figure 5). The more common pattern was named $C$, corresponding to the sequencing results of GenBank accession no. X51822. The second pattern was 


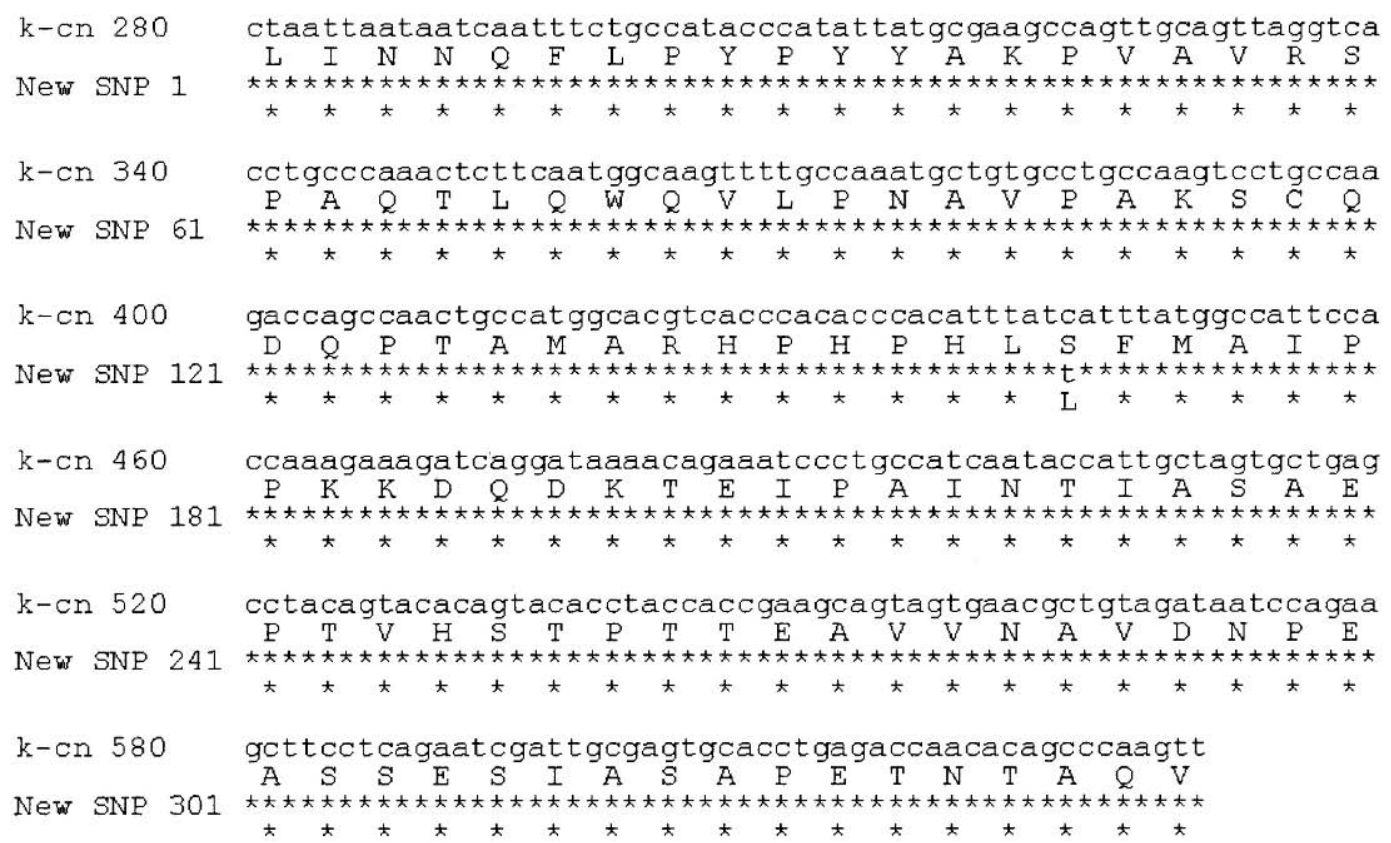

Figure 6. The sequence comparison of nucleotide positions 280 to 630 of the published $\kappa$-casein locus (CSN3) sequence (GenBank accession no. X51822) and the codified protein sequence (first and second sequence respectively) vs. the DNA and deduced AA sequences (GenBank accession no. AY444505) found in the present work (new single-nucleotide polymorphism: third and fourth sequence respectively). Identical nucleotides and AA are replaced by * and the substitutions are written as letter.

found only in one sample and was named $T$. Sequencing of the new pattern revealed the presence of a transition $\mathrm{C} \rightarrow \mathrm{T}$ at position 443 of the referring sequence, resulting in the deduced AA exchange Ser $_{104} \rightarrow$ Leu $_{104}$ (Figure 6). Both AA are neutral and therefore the exchange should not be revealed by protein electrophoresis. The new SNP (GenBank accession no. AY444505) was found at the heterozygous condition in one sample of Sopravissana breed (Table 1). Bastos et al. (2001) found a monomorphism at ovine CSN3 exon 4 by SSCP. Recently, a SNP was found by LightCycler-based realtime PCR (Feligini et al., 2003) that did not result in an AA exchange and which showed a rather high frequency (22 and 12\%) in the 2 breeds analyzed (Sarda and Paska). The low frequency of the T mutation at CSN3 makes this SNP less interesting, although an intriguing question about this locus is the high genetic variation found in cattle and goats (Prinzenberg et al., 1999; Yahyaoui et al., 2001, 2003; Jann et al., 2004) compared with the almost complete absence of variation in sheep deducible from literature, except for the synonymous mutation above mentioned (Feligini et al., 2003).

\section{Casein Haplotypes}

Frequencies of CSN1S1-CSN2 haplotypes in the 3 breeds are shown in Table 2, both under the hypothesis of independent segregation (I) and taking into account the association among loci (A). Substantial differences between the 2 frequencies were not observed, as indicated by the $\chi^{2}$ test performed with $\mathrm{EH}$ software allowing allelic association. In fact, the $\chi^{2}$ probability values were never significantly different from zero (Comisana: $P>0.138$; Sarda: $P>0.781$; Sopravissana: $P>0.309$ ). Therefore, a situation of linkage equilibrium between the 2 SNP seems to occur in the breeds. The predominant haplotype CSN1S1-CSN2 was T-A in all breeds, showing the highest frequency $(0.723)$ in Sopravissana, where a balanced distribution was observed for the other 3 haplotypes, which was not the case in the other breeds. In Sopravissana, the $C$ - $G$ haplotype showed a frequency value of 0.091 , which was higher than expected (0.034) for independent segregation. The $C$ - $G$ haplotype occurred in both Comisana and Sarda at a lower frequency under the hypothesis of allelic association than that of independent segregation. The different haplotypes at the CSN1S1-CSN2 loci of Sopravissana might be explained by the different productive aptitude of the breed compared with Sarda and Comisana. However, a larger number of animals would be required to confirm this hypothesis, as well as data from other ovine breeds, possibly characterized by different productive aptitudes.

For $C S N 3$, the unique heterozygous animal $(C T)$ was homozygous for the more common SNP at the other 2 loci (genotype $C S N 1 S 1^{*} T T, C S N 2 * A A$ ), resulting in 2 
haplotypes: $\quad C S N 1 S 1 * T-C S N 2 * A-C S N 3 * C$, and $C S N 1 S 1^{*} T-C S N 2 * A-C S N 3^{*} T$, the latter carrying the CSN3 SNP identified here.

\section{CONCLUSIONS}

Three SNP were identified and characterized at CSN1S1, CSN2, and CSN3 ovine genes, resulting in 3 AA substitutions. For CSN1S1 and CSN2, the high frequency of the mutations, ranging from 0.12 to 0.26 and found in all 3 breeds, indicates an opportunity to consider the polymorphisms in investigations of biodiversity and quantitative traits. The 2 SNP were found in 2 exons resulting in protein polymorphisms of bovine CSN1S1 and CSN2. Both exons code for a large part of the mature proteins (in cattle: 51 AA out of 199 for $\alpha_{\mathrm{s} 1}$-casein and $166 \mathrm{AA}$ out of 209 for $\beta$-casein). However, it is noteworthy that the most common CSN1S1 polymorphism in cattle, resulting in the 2 genetic variants $B$ and $C$, involves AA 192 (Grosclaude et al., 1972), which is close to the ovine AA 187 polymorphism identified here.

The apparently less important CSN3 polymorphism was detected in one animal out of the 138 analyzed. The detection of this SNP responsible for an AA substitution in a local breed may reflect on the breed's productive aptitude. High conservation of the primary structure of $\kappa$-casein is found in different species around the protease-sensitive peptide bond between AA 105 and 106 (Mercier et al., 1976). In sheep, it seems that the exon 4 sequence is highly conserved, whereas the only protein polymorphism found involves an AA at position 104, just before the peptide bond that is cleaved by rennet chymosin. Sheep's milk has been used exclusively to make cheese for ages, which may have played a crucial role in the ovine CSN3 molecular evolution.

\section{ACKNOWLEDGMENT}

Research partially supported by MURST contract 2001077279.

\section{REFERENCES}

Alais, C., and P. Jollès. 1966. Isolation, purification, and analysis of two $\kappa$-casein like fractions from sheep caseins. J. Dairy Sci. 50:1555-1561.

Barroso, A., S. Dunner, and J. Canon. 1999. A multiplex PCR-SSCP test to genotype bovine beta-casein alleles $\mathrm{A}^{1}, \mathrm{~A}^{2}, \mathrm{~A}^{3}, \mathrm{~B}$, and $\mathrm{C}$. Anim. Genet. 30:322-323.

Bassam, B. J., G. Caetano-Anolles, and P. M. Gresshoff. 1991. Fast and sensitive silver staining of DNA in polyacrylamide gels. Anal. Biochem. 196:80-83.

Bastos, E., A. Cravador, J. Azevedo, and H. Guedes-Pinto. 2001. Single strand conformation polymorphism (SSCP) detection in six genes in Portuguese indigenous sheep breed "Churra da Terra Quente.” Biotechnol. Agron. Soc. Environ. 5:7-15.
Bell, K., and H. A. McKenzie. 1967. The whey proteins of ovine milk. $\beta$-lactoglobulins A and B. Biochim. Biophys. Acta 147:123-134.

Boisnard, M., D. Hue, C. Bouniol, J. C. Mercier, and P. Gaye. 1991. Multiple mRNA species code for two non-allelic forms of ovine alpha s2-casein. Eur. J. Biochem. 201:633-641.

Caroli, A., O. Jann, E. Budelli, P. Bolla, S. Jäger, and G. Erhardt. 2001. Genetic polymorphism of goat $\kappa$-casein (CSN3) in different breeds and characterization at DNA level. Anim. Genet. 32:226-230

Chessa, S., P. Bolla, C. Dario, E. Pieragostini, and A. Caroli. 2003a. Polimorfismi genetici lattoproteici nella razza ovina Gentile di Puglia: monitoraggio mediante focalizzazione isoelettrica. Sci. Tecn. Latt-Cas. 54:191-198.

Chessa, S., E. Budelli, K. Gutscher, A. Caroli, and G. Erhardt. 2003b. Simultaneous identification of five $\kappa$-casein (CSN3) alleles in domestic goat by polymerase chain reaction single strand conformation polymorphism. J. Dairy Sci. 86:3726-3729.

Chianese, L., G. Garro, R. Mauriello, P. Laezza, P. Ferranti, and F. Addeo. 1996. Occurrence of five $\alpha_{\mathrm{s} 1}$-casein variants in ovine milk. J. Dairy Res. 63:49-59.

Chiofalo, L., and P. Micari. 1987. Attuali conoscenze sulle varianti delle proteine del latte nelle popolazioni ovine allevate in Sicilia. Osservazioni sperimentali. Sci. Tecn. Latt-Cas. 38:104-114.

Dall'Olio, S., R. Davoli, and P. Bosi. 1989. Ricerche elettroforetiche delle proteine del latte nella razza ovina Sopravissana. Sci. Tecn. Latt.-Cas. 40:186-194.

Di Stasio, L., and P. Mariani. 2000. The role protein polymorphism in the genetic improvement of milk production. Zoot. Nutriz. Anim. 26:69-90.

Erhardt, G. 1989. Evidence for a third allele at the $\beta$-lactoglobulin ( $\beta$-lg) locus of sheep milk and its occurrence in different breeds. Anim. Genet. 20:197-204.

Feligini, M., P. Parma, R. Aleandri, G. F. Greppi, and G. Enne. 1998. PCR-RFLP test for direct determination of beta-lactoglobulin genotype in sheep. Anim. Genet. 29:473-474.

Feligini, M., V. Cubric Curik, P. Parma, G. F. Greppi, and G. Enne. 2003. A single nucleotide polymorphism in the sheep $\kappa$-casein (CSN3) coding region. Page 100 in Proc. 54th EAAP Mtg., Rome, Italy.

Ferranti, P., A. Malorni, G. Nitti, P. Laezza, R. Pizzano, L. Chianese, and F. Addeo. 1995. Primary structure of ovine $\alpha_{\mathrm{s} 1}$-casein: localization of phosphorylation sites and characterization of genetic variants A, C and D. J. Dairy Res. 62:281-296.

Ferranti, P., R. Pizzan, G. Garro, S. Caira, L. Chianese, and F. Addeo. 2001. Mass spectrometry-based procedure for the identification of ovine casein heterogeneity. J. Dairy Res. 68:35-51.

Ferretti, L., P. Leone, and V. Sgaramella. 1990. Long range restriction analysis of the bovine casein genes. Nucleic Acids Res. 18:6829-6833.

Grosclaude, F., M. F. Mahé, J. C. Mercier, and B. Ribadeau-Dumas. 1972. Caractérisation des variants génétiques des caséines $\alpha_{\mathrm{s} 1}$ et $\beta$ bovines. Eur. J. Biochem. 26:328-337.

Grosclaude, F., G. Ricordeau, P. Martin, F. Remeuf, L. Vassal, and J. Bouillon. 1994. Du gène au fromage: le polymorphisme de la caséine $\alpha_{\mathrm{s} 1}$ caprine, ses effets, son évolution. INRA Prod. Anim. $7: 3-19$.

Hall, T. A. 1999. BioEdit: A user-friendly biological sequence alignment editor and analysis program for Windows 95/98/NT. Nucl. Acids. Symp. Ser. 41:95-98.

Jann, O., G. Ceriotti, A. Caroli, and G. Erhardt. 2002a. A new variant in exon VII of bovine $\beta$-casein gene (CSN2) and its distribution among European breeds. J. Anim. Breed. Genet. 119:65-68.

Jann, O., E. M. Prinzenberg, H. Brandt, J. L. Williams, P. AjmoneMarsan, P. Zaragoza, C. Özbeyaz, and G. Erhardt. 2002b. Intragenic haplotypes at the bovine CSN1S1 locus. Arch. Tierzucht. 45:13-22.

Jann, O., E. M. Prinzenberg, G. Luikart, A. Caroli, and G. Erhardt. 2004. High polymorphism in the $\kappa$-casein (CSN3) gene from wild and domestic caprine species revealed by DNA sequencing. J. Dairy Res. 71:188-195. 
King, J. W. B. 1966. The caseins of sheep's milk. Pages 427-431 in Polimorphismes Biochimiques des Animaux. Inst. Nat. Recherche Agronomique, Paris, France.

Martin, P. 1993. Polymorphisme génétique des lactoprotéines caprines. Lait 73:511-532.

Mercier J. C., J. M. Chobert, and F. Addeo. 1976. Comparative analysis of the amino acid sequences of caseinomacropeptides from seven species. FEBS Lett. 72:208-214.

Pilla, F., C. Bevilacqua, C. Leroux, A. Fraghi, and P. Martin. 1998. Genotyping of $\alpha_{-\mathrm{s} 1}$ casein in sheep. Anim. Genet. 29:472-473.

Pirisi, A., G. Piredda, C. M. Papoff, R. Di Salvo, S. Pintus, G. Garro, P. Ferranti, and L. Chianese. 1999. Effects of sheep alpha s1casein CC, CD and DD genotypes on milk composition and cheesemaking properties. J. Dairy Res. 66:409-419.

Prinzenberg, E. M., I. Krause, and G. Erhardt. 1999. SSCP analysis at the bovine CSN3 locus discriminates six alleles corresponding to known protein variants (A, B, C, E, F, G) and three new DNA polymorphisms (H, I, A1). Anim. Biotechnol. 10:49-62.

Rampilli, M., F. Locci, M. G. Bardin, P. Bolla, and A. Caroli. 1992. Stabilità termica del siero di latte ovino: Effetto del genotipo $\beta$ lattoglobulinico Pages 167-174. in Proc. XXVII Simp. Int. Zoot., Milano, Italy. Arti Grafiche G.S.C., Sesto S. Giovanni (Mi), Italy.

Ramunno, L., G. Cosenza, A. Rando, N. P. P. Macciotta, M. Pappalardo, and P. Masina. 1997. Identification of carriers of the Welsh CASA1 variant using an allele-specific PCR method. Anim. Genet. 28:154-155.
Ramunno, L., P. Mariani, M. Pappalardo, A. Rando, M. Capuano, P. Di Gregorio, and G. Cosenza. 1995. Un gene ad effetto maggiore sul contenuto di caseina $\beta$ nel latte di capra. Proc. XI Congr. Naz. A.S.P.A. $185-186$.

Rando, A., L. Ramunno, and P. Masina. 2000. Mutations in casein genes. Zoot. Nutriz. Anim. 26:105-114.

Raymond, M., and F. Rousset. 1995. GENEPOP (version 1.2): Population genetics software for exact tests and ecumenicism. J. Hered. 86:248-249.

Richardson, B. C., and L. K. Creamer. 1976. Comparative micelle structure $\mathrm{v}$. the isolation and characterization of the major ovine caseins. NZ J. Dairy Sci. Technol. 11:46-53.

Russo, V., L. Chiofalo, and P. Micari. 1979. Polimorfismo delle proteine del latte nelle pecore di razza Comisana. Riv. Zoot. Vet. 4:239-244.

Threadgill, D. W., and J. E. Womack. 1990. Genomic analysis of the major bovine milk proteins genes. Nucleic Acids Res. 18:69356942.

Xie, X., and J. Ott. 1993. Testing linkage disequilibrium between a disease gene and marker loci. Am. J. Human. Genet. 53:1107.

Yahyaoui, M. H., A. Angiolillo, F. Pilla, A. Sanchez, and J. M. Folch. 2003. Characterization and genotyping of the caprine kappa casein variants. J. Dairy Sci. 86:2715-2720.

Yahyaoui, M. H., A. Coll, A. Sanchez, and J. M. Folch. 2001. Genetic polymorphism of the caprine kappa casein gene. J. Dairy Res. 68:209-216. 